\title{
First Report on Molecular Identification of Caulerpa Green Algae from Mandangin Island Indonesia Using Partial 18SrRNA Genes
}

\author{
Nwet Darli Kyaw Zaw ${ }^{1.3}$, Putu Angga Wiradana ${ }^{1}$, Sin War Naw ${ }^{1.4}$, Aondohemba Samuel \\ Nege $^{1.5}$, Mochammad Amin Alamsjah ${ }^{2 *}$, Rizhar Eman Karunia Akbar ${ }^{1}$ and Fahror Rosi ${ }^{1}$ \\ ${ }^{1}$ Fisheries and Marine Biotechnology Program, Faculty Fisheries and Marine Science, Universitas \\ Airlangga, Surabaya 60115, Indonesia \\ ${ }^{2}$ Department of Marine, Faculty of Fisheries and Marine, Universitas Airlangga, Surabaya 60115, \\ Indonesia \\ ${ }^{3}$ Department of Chemistry, Yadanabon University, Mandalay City, Myanmar \\ ${ }^{4}$ Department of Chemistry, Mandalay University, Mandalay City, Myanmar \\ ${ }^{5}$ Department of Fisheries and Aquaculture, Federal University of Agriculture, P.M.B 2373, Makurdi, \\ Nigeria
}

*Correspondence :

alamsjah@fpk.unair.ac.id

Received : 2020-05-18

Accepted : 2020-07-27

Keywords :

18SrRNA, Caulerpa, Macroalgae, Mandangin Indonesia

\begin{abstract}
Caulerpa is one of the seaweed that grows naturally in Indonesian waters such as those in Mandangin Island. This study aimed to identify Caulerpa sp. based on molecular analysis using certain genetic markers. This research is expected to provide information on the identification of macroalgae from Indonesia waters, especially Mandangin Island, Madura with the use of molecular analysis based on 18SrRNA primers. The two green seaweed samples from the Caulerpa genus in this study were successfully analyzed using 18SrRNA primers. The BLAST results of samples 1and 2 are related to Caulerpa taxifolia 18SrRNA, but in the phylogenetic tree result, Sample 1 was more closely related to Caulerpa sertularioides $f$. longipes. 18SrRNA primers have been used for molecular identification of green seaweed from Mandangin for the first time and this shows that barcode markers can be used for molecular identification of seaweed, specifically Caulerpa in the waters of Mandangin Island, Indonesia.
\end{abstract}

\section{INTRODUCTION}

One of the marine resources that have high economic value is seaweed. Seaweed can be used as a source of natural products. One type of seaweed whose potential is still not widely utilized is the green seaweed of the genus Caulerpa. Caulerpa is one of the genera of green algae that can grow in tropical and subtropical regions and it is the object of this research because it has not been well studied up to date.

The potential development of Caulerpa is quite good because this seaweed contains nutrients needed by the body and has been known as a traditional food by coastal communities in Indonesia. Several types of bioactive substances found in Caulerpa such as alkaloids, flavonoids, terpenoids, tannins, and saponins can be used as food and pharmaceutical ingredients (Lantah et al., 2017). Geographically, Mandangin Island is located at coordinates $113^{\circ} 12^{\prime} 8.45^{\prime \prime}$ $113^{\circ} 13^{\prime} 31.21^{\prime \prime} \mathrm{E}$ and $7^{\circ} 18^{\prime} 22.38^{\prime \prime}-7^{\circ} 18^{\prime}$ $52.92 "$ S. Mandangin Island is included in the administration of the Sampang 
Regency and one of its villages; Pulau Mandangin. Sampang Village has sea borders throughout the island. Pulau Mandangin Village is divided into 3 kindreds which were called by Candin, Kramat, and Barat. Mandangin Island has the potential as a location for the development of seaweed cultivation, one of them is Caulerpa.

However, some reports mention that the invasive growth of Caulerpa taxifolia in nature can affect the diversity of coastal ecosystems. That is because the active compound called "Caulerpin" inhibits the multixenobiotic resistance mechanism of the sea sponge Geodia cydonium which can protect marine organisms from various water pollutants (Shanmugam et al., 2018). One identification method that can be used for seaweed is the determination of morphology, this refers to the research of Dawson (1954) but the weaknesses that occur in morphological identification is the difficulty in distinguishing intra species, species reference is still limited, and images of species referred to were still in the form of hand drawings hence they had a relatively low level of accuracy when compared with photographic results.

Research on molecular identification of Caulerpa is still rarely performed considering the abundant availability of this species in nature (Camacho et al., 2015) including coastal waters in Indonesia. The process of molecular identification of macroalgae also has constraints such as the difficulty of obtaining high purity in the DNA extraction process (Doyle and Doyle, 1990), high inhibitors in the extracted algae (Hoarau et al., 2007) and there are still few available DNA sequences of partial DNA genomes contained in Gen Bank.

Genetic markers have been widely used in molecular identification of macroalgae such as rbcL and 18SrRNA (Mahendran and Saravanan, 2017), DNA barcodes (Camacho et al., 2015; Poong et al., 2014; Saunders and Moore, 2013; Kher et al., 2011; Le Gall and Saunders, 2010; Mattio and Payri, 2010; Lane et al.,
2007), 18SrDNA (Soylu and Gönülol, 2012), microsatellite (Varela-Álvarez et al., 2006).

This study aims to identify Caulerpa sp. based on molecular analysis using 18SrRNA markers. This research is expected to be a breakthrough that will contribute to the identification of macroalgae from Indonesian waters, especially in the waters of Mandangin Island, Madura, East Java on a molecular basis based on the 18SrRNA markers.

\section{METHODOLOGY}

\section{Place and Time}

This research was conducted between September - December 2019. Samples were collected from Mandangin Island coastal waters and then treated in Cell and Molecular Biology Laboratory, Faculty of Science and Technology, Universitas Airlangga.

\section{Research Material}

The tools used in the study include plastic bags, cooler box, freezer $\left(-20{ }^{\circ} \mathrm{C}\right)$, digital scale, centrifuge, microtube, incubator, NanoDrop 2000 (Thermo Scientific), electrophoresis equipment, thermocycler machine, pipette, and digital camera (Digitec, Japan).

The materials used to support this study were TRIzol, chloroform, ethanol, $\mathrm{NaOH}$, EDTA, HEPES, universal primer 18SrRNA, agarose gel, and TBE buffer.

\section{Research Design}

The samples of Caulerpa were identified with DNA extraction, PCR, sequencing, and phylogenetic analysis. DNA extraction was carried out using the Trizol reagent method according to Chomczynski (1993). Sequencing was carried out by referring to the standard Sanger Sequencing method. Contiq sequence was aligned (multiple alignments) with the database using ClustalW and a phylogenetic tree was made with 1000 replications using the Neighbor-Joining (NJ) method with 
MEGA 7 (Molecular Evolutionary Genetics Analysis) Software.

\section{Work Procedures}

\section{Sampling Location}

The two samples of Caulerpa sp. were obtained from the intertidal zone in the coastal waters of Mandangin Island, Madura, East Java, Indonesia (Figure 1).
The obtained samples were then washed using fresh water and placed into plastic bag with a label and stored in a cooler box during transportation to the Cell and Molecular Biology Laboratory, Study Program of Biology, Faculty of Science and Technology, Universitas Airlangga, Surabaya where the sample was stored in a freezer at $-20{ }^{\circ} \mathrm{C}$ upon arrival at the laboratory.

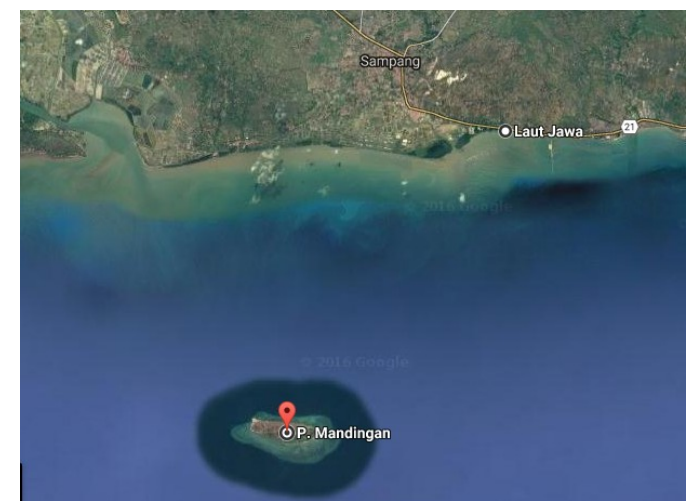

Figure 1. Map of the sampling location of Caulerpa sp. taken with Google Maps.

\section{DNA Extraction}

DNA extraction was carried out using the Trizol reagent method according to Chomczynski (1993). First, a sample weighing up to $250 \mathrm{~g}$ was added to 750 $\mathrm{mL}$ of Trizol then mixed by pipetting. Algae contain a lot of fat hence lysate was centrifuged at a speed of $12,000 \times \mathrm{g}$, at 4 ${ }^{\circ} \mathrm{C}$ for 5 minutes. The resulting supernatant was then incubated for 5 minutes. After incubation, $200 \mu \mathrm{L}$ of chloroform was added and incubated for 2-3 minutes, followed by sample centrifugation, $12,000 \times \mathrm{g}$ speeds at $4{ }^{\circ} \mathrm{C}$ for 15 minutes.

The results of the centrifuge formed three layers and DNA was in the interphase (middle layer) and $300 \mu \mathrm{L}$ $100 \%$ ethanol (EtOH) was added and incubated for 2-3 minutes followed by centrifugation for 5 minutes with $2,000 \times$ $\mathrm{g}$ speed at of $4{ }^{\circ} \mathrm{C}$. The pellet was obtained by removing the supernatant. The result of the pellet in $1 \mathrm{~mL} 0.1 \mathrm{M}$ Na citrate in $10 \%$ EtOH with a pH of 8.5 was incubated for 30 minutes while inverting slowly every 10 minutes for 30 minutes. After 30 minutes, it was centrifuged using $2,000 \times$ g speed at $4{ }^{\circ} \mathrm{C}$ for 5 minutes. The supernatant was discarded and this process was repeated once again. The pellet was re-suspended in $1.5 \mathrm{~mL} 75 \%$ EtOH and incubated for 10-20 minutes.

The resulting product of incubation was centrifuged at $2,000 \times \mathrm{g}$ speed at $4{ }^{\circ} \mathrm{C}$ for 5 minutes. The supernatant was again discarded while the pellet was dried at room temperature for 5-10 minutes. The pellet was re-suspended in $0.3-0.6 \mathrm{~mL}$ of $8 \mathrm{Mm} \mathrm{NaOH}$ and centrifuged for 10 minutes using $12,000 \times \mathrm{g}$ speed at $4{ }^{\circ} \mathrm{C}$. The supernatant was taken and put into a new microtube while the $\mathrm{pH}$ was adjusted to 7-8 with HEPES and $1 \mathrm{mM}$ EDTA was added and stored at $-20{ }^{\circ} \mathrm{C}$. The obtained level of DNA purity was measured using NanoDrop followed by the electrophoresis process.

\section{Polymerase Chain Reaction (PCR)}

The PCR reaction was carried out on a Thermocycler machine in the following sequence in Table 1 . The total cycle of this process was 35 cycles. The primer used in the PCR reaction is a universal primer 
18SrRNATrackittm $1 \mathrm{~Kb}$ Plus DNA Ladder

(Table. 1).

Table 1. Primers and PCR condition (Mahendran and Saravanan, 2017).

\begin{tabular}{|c|c|c|}
\hline Primer Name & Sequence [5'-3'] & PCR Condition \\
\hline 18SrRNA 1 & $\begin{array}{l}\text { CGATCTATTCAT- } \\
\text { TCAATATTTC }\end{array}$ & $\begin{array}{l}\text { Initial } 2 \mathrm{~min} \text {; denaturation at } 95^{\circ} \mathrm{C}, 35 \text { cycles of } 93^{\circ} \mathrm{C} \text { for } \\
1 \mathrm{~min}, 54^{\circ} \mathrm{C} \text { annealing for } 45 \mathrm{sec}, 72^{\circ} \mathrm{C} \text { extension for } 2 \\
\text { min, followed by } 72^{\circ} \mathrm{C} \text { final extension for } 10 \text { min. }\end{array}$ \\
\hline 18SrRNA 2 & $\begin{array}{l}\text { TCTAGCACACG- } \\
\text { AAAGTCGAAGT }\end{array}$ & $\begin{array}{l}\text { Initial } 2 \mathrm{~min} \text {; denaturation at } 95^{\circ} \mathrm{C}, 35 \text { cycles of } 93^{\circ} \mathrm{C} \text { for } \\
1 \mathrm{~min}, 51^{\circ} \mathrm{C} \text { annealing for } 45 \mathrm{sec}, 72^{\circ} \mathrm{C} \text { extension for } 2 \\
\text { min, followed by } 72^{\circ} \mathrm{C} \text { final extension for } 5 \text { min. }\end{array}$ \\
\hline
\end{tabular}

The amplification product was separated with $1 \%$ agarose gel $(\mathrm{m} / \mathrm{v})$ in $1 \mathrm{X}$ TBE buffer (addition of $0.75 \mu \mathrm{L}$ Floro safe DNA strain) at $90 \mathrm{~V}$ for 15 minutes. 1000 bp DNA Ladders are used as long markers of product DNA bases. DNA bands were then documented using a digital camera (Digitec, Japan). The 18SrRNA DNA band appeared as a single band at a base length of $1000 \mathrm{bp}$.

\section{Sequencing and Phylogenetic Analysis}

Sequencing was carried out by the $1^{\text {st }}$ BASE DNA Laboratory, Genetics Science, Singapore by referring to the standard Sanger Sequencing method to obtain contiq results and the results of primary and forward sequences. Contiq sequence results are aligned (multiple alignments) with the database stored in Gen bank referred to National Center for Biotechnology Information (NCBI) through the BLAST (Basic Local Alignment Searching Tool) program to obtain a percentage of similarity (sample similarity) by comparing the Caulerpa sample with other species in the database.

Contiq sequences of the 18SrRNA Caulerpa gene were aligned (multiple alignment) with the partial 18SrRNA genes selected in the database using ClustalW and a phylogenetic tree was made with 1000 replications using the Neighbor-Joining (NJ) method with MEGA 7 (Molecular Evolutionary Genetics Analysis) Software.

\section{Data Analysis}

The data obtained was numerically described since it needed no statistical package.

\section{RESULTS AND DISCUSSION}

Globally, the genus of green algae Caulerpa has a total of 85 species (Guiry et al., 2014) which are broadly distributed in tropical to sub-tropical waters. One importance of the presence of Caulerpa species is that they can form one of the best coastal ecosystems that have been widely explained by many reports on the invasion of C. taxifolia (M.Vahl), C. agardh and $C$. cylindracea Sonder (formerly called C. racemosa var. Cylindraceae (Sonder) (Belton et al., 2014). Different studies on the formation of population invasion of $C$. taxifolia and $C$. cylindraceae in the Mediterranean focused on the spread of these species and the impact of their invasion on the surrounding aquatic ecosystems (Meinesz et al., 1993; Verlaque and Fritayre, 1994; Chisholm et al., 1997; Jousson et al., 1998; Piazzi et al., 2001; Balata et al., 2004; McKinnon et al., 2009; Bulleri et al., 2010; Vázquez-Luis et al., 2010; Gennaro and Piazzi, 2011; Oakes et al., 2011; Pacciardi et al., 2011).

The spread of green algae also provides pharmaceutical benefits such as antioxidants, anticoagulants, antimutagenic, antibacterial and anticancer activities which must be taken into consideration (Cho et al., 2011; Vinayak et al., 2011; Farasat et al., 2013). According to a previous study, among several green algae species, Caulerpa sp. had an inhibitory effect on telomerase in MOLT-4 
cells while some species were reported to have antitumor activity (Kanegawa et al., 2000). Caulerpa sp. harvested from the Yucatan Peninsula, Mexico showed a higher phenolic content than other seaweeds around the environment (Zubia et al., 2007). "Caulerpin" which is an alkaloid that can be isolated from Caulerpa sp. has antitumor activity but there are very limited studies available on the compound (Liu et al., 2009). A study also mentioned that the antioxidant and phenolic content of $C$. racemosa was higher than the red algae species (Matanjun et al., 2008).

From our observations, part of the results of this study varies with those of other species, hence we hypnotized that some compounds in Caulerpa could be inhibitors and even impurities in the DNA extraction process as this is seen from the low quantity of DNA obtained from the extraction process after being read on NanoDrop 2000 (Thermo Scientific). This hypothesis is supported by the study of Setyawan (2019) who observed that compounds such as alginate in the Sargassum species are impurities, making it difficult to extract DNA from these algae. Thus, the process of depigmentation and removal of genomic DNA impurities in algae needs to be carried out in DNA extraction. The acidic alginate removal in the process of extracting algal DNA can give a positive effect in reducing impurities such that it can increase the number of peaks on the chromatogram when compared using standard $\mathrm{CTAB}$. The feasibility of the DNA extraction process with Trizol can be further studied and compared with other extraction methods using higher DNA quantity in the future.

\section{Morphological Identification of Caulerpa sp.}

Morphological identification results showed that Sample 1 (Figure 2A) has similarities with Caulerpa racemosa (Forsskal) J. Agardh 1873. C. racemosa consists of several branches connected by stolon attached to the sandy substrate by rhizoid. The branches are several centimeters apart and grow to a height of $30 \mathrm{~cm}$. The shoots are round hence the species is also called sea grapes and $C$. lentilifera.

Morphological identification results showed that Sample 2 (Figure 2B) had similarities with Caulerpa sertularioides (S.G Gmelin) with the description of branch-like feathers, flat and upright as high as 3-5 $\mathrm{cm}$ and $1-2 \mathrm{~mm}$ in diameter. Rhizoid is attached to the substrate. The opposite branchlets are attached to the midrib, slightly curved upward and tapered at the base and tip. The midrib is slightly flat and light green-yellow. This species bears little resemblance to $C$. taxifolia.
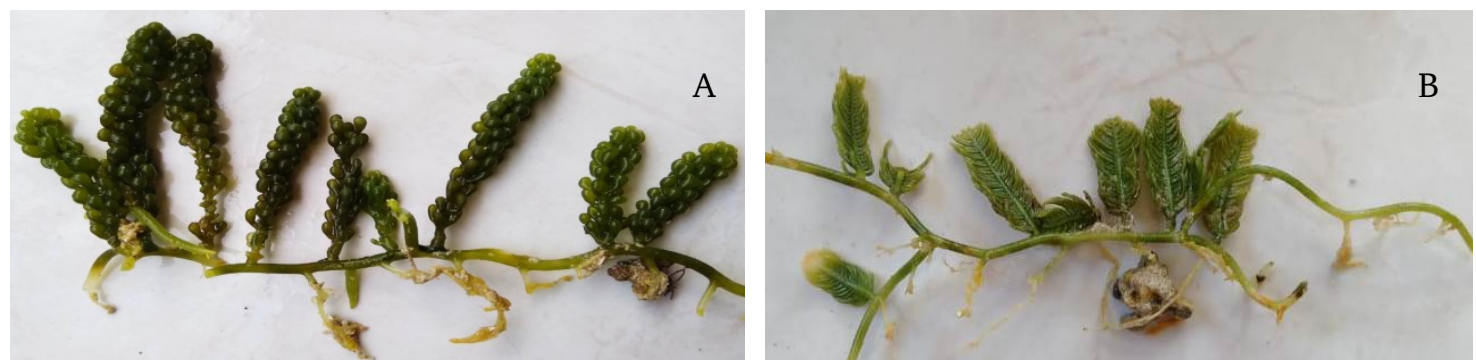

Figure 2. Morphology of Caulerpa sp. Which was collected from Mandangin Island, Madura, East Java. (A) Sample 1 and (B) Sample 2.

\section{SrRNA Amplification}

The results of the amplification of the PCR reaction mixture, the temperature and time conditions as described in the method showed the 18SrRNA gene used as a primer for Caulerpa sp. samples gave rise to a thin single band at around $1000 \mathrm{bp}$ (Figure 3). 


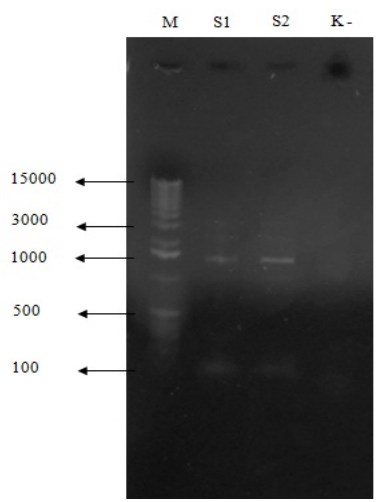

Figure 3. PCR results with 18SrRNA primers in Caulerpa sp. samples. The gene is amplified in the presence of a single band at a length of about 1000 bp. Description: M: Marker; S1: Sample 1; S2: Sample 2 and K-: Negative control.

The 18SrRNA primer used in this study was based on the research of Mahendran and Sarasvanan (2017) that studied out molecular identification of the green algae Ulva lactuca and Caulerpa taxifolia collected from rocky coasts around the coastal areas of the new port of Tuticorin, the Gulf of Mannar, Southeast Coast of India. In terms of yield, the rRNA yield of this study appears lower than the report on Symbiodinium sp. by Santiago-Vázquez et al. (2006) who obtained a high quantity of RNA using Trizol $^{\circledR}$ reagent and found their result 3-4 times higher than their findings using RNeasy $^{\circledR}$. Such variations could be as a result of location, macroalgae adaptation, and evolution.

\section{Sequencing Results}

Sequencing results for Caulerpa sp. had the following nucleotide:

a. Nucleotide of Sample 1

CGTAGTGGACGGCTCGGTTCCCGTG TCGATGAAGGACGTAGCGAAATACG AAAGGTGTTGCGAATTGCAAGATTTC GTGAGTCAATGAATATCCGAATGCAT TGTCGTCCCTTCGCAGCTTCTGGGTT GCAAGGGGCGCGTCGGCAACATCGG CTAATTGTCGACCTTCATATGAGTCT CTTTTGTTCACTCTCTTACTGAGCGA GTGTGCTGGATTCTGTATGAAGCAGT GGTTCAGATGAGCAAGCATTAACTTT TCCATACCTGTATCTGTGGCTGAATG CTTGTGATGACTCCCTCTCACAACTA TCGACTACTGATTTTGAGATTAACGA
CAGTATATTTGTGACTTGCATCACTC TATGTGCTCTTGTCCTATAGCAAGCT CAATCGCATGAGATTCGAAGGTTGCC TAGAAATCTGTGCTCAAAAATAGTAG TCTGGTTCTGTCAGAACGTGTATCTG TATGCCTTTGACGATGTTGTCGGCGA GGAAACCCGCTGAACTTAAGCATATC AATAAGCGGAGGAAAAGAAACCAAT TTGGATGCCCCTAGTACTGGCGAGC GAACAAGCGATGCGGTTGGCGTACG TTCTCCAGAAGTTCGCTTCGTTATGA GGAAGGCAACCAGACTGAGTTCCAA ATTCTCGGTAAGCTTTATATTGAAGG TTACAACGTGGATCTAGTGTTCGAAA ATTTGGCGGACTTCCCTGGAGCGAA GTACGACGCTAAGACCGTCAAGTTC GTCCTGGAGTCTCTAACCACTGGTTT CGTTGATTGCCGCTAACAGGTGGCG ACGTCACTCTCGAGAGAACTTTGATA CATCTTCGGCTATTGGCGTCGTAGCG AGAGTGACAGAGAATGATCGACAAT ACGGCGCTTGACATGAGCAGCACTC GGGCGAGAACCATCAGGACATCAGA AACA

b. Nucleotide of Sample 2 GCCCCGGTTTTCGGCCGGCAATTCCC AGTAGGCGTCGGAAAAACAAACGTT TGCCTTTACGGTAAAAAGGCTTTACT TTCGGAATCCGGTTAAGGCGTTGGG TAATTAACGTAGACCGGTGCCCGATG GTTCCGGAAGCGAAAGGGTAACAGG CGGCCGGTCCAAGCCTAGTTACGAG CACGATGATGTATGGTTCGGTTTCCA CTGGAGCCGGCTCCCTGTCGACCTTT ACGCAAGAAGCGACGGTCAGATACC GGCCTCGATCGCGGATGCGATAACA 
GCCCGGGTTCAACACGCAACTTGAG ACAAGTTCGTTGATGGTAAGAGTATG GCATATCAACATTTTCGTAGGTGAAC CTGCGAAAGGATCATTATCGGCAAAT TCTATTTATGTATACACTACTGTGTG TCTATATTCTTTGTGTAAAGACATGG CTATGTTGTAATGAGATGTGTTGTTA TTATTGTCTAAAGCATGTTCGTAGTT GGACGGCATCGGTTCCCGTGTCGAT GAAGGACGTAGCGAAAGTTTACGAA AGGTGTTGCGTAATTGCAAGATTTCG TGAGTCAATGAATAATCCGAATGCAT TGTCGTCCCTTCGCAGCTTCGGTTGC AAGGGGCGCGTCGGCAACATCGGCA CTATAATTGTCGACCTTCATAGTCTC TCTTGTATACTCTCTCTTACTGAGAG CAAGGTTGCTCGACTCTATGAAGCAG GTTTGGTTCAGTGAGCAAGCATTCCA TACGCCGATGTGGCTATCGCTTGTCG ACGACTCCCTCTCGGACTATCGACTA CTGACTGAGATTAACGACAGTATTGT GACTTGCATACTCTATGTGCTTGTCC
TATAGCAATCAATCGCTGAGATTGAA TGCCTAGAAACTGTGCTCAGCAATAG TAGTCTGGTGNTNTCAGAACGTGTA TCTATATTTTGACGATGTTGTCGGCG AGGAAACCCGCTGAACTTAAGCATAT CACTAAGCGGAGGAAAAGAAACCAA TTTGGATGC

\section{BLAST Analysis}

The results of the analysis with BLAST, which is an online search engine that matches a query sequence with database sequence showed that both Caulerpa sp. samples had similarities with C. taxifolia 18SrRNA gene with a percentage identity of sample 1 at $88.87 \%$ lower than that of sample 2 which was $95.20 \%$. The BLAST results for each sample can be seen in the following Table 2 and Table 3:

Table 2. Result of BLAST analysis of sample 1.

\begin{tabular}{cccccccc}
\hline No. & Description & $\begin{array}{c}\text { Max } \\
\text { Score }\end{array}$ & $\begin{array}{c}\text { Total } \\
\text { Score }\end{array}$ & $\begin{array}{c}\text { Query } \\
\text { Cover }\end{array}$ & E-Value & $\begin{array}{c}\text { Per. } \\
\text { Identity }\end{array}$ & Accession \\
\hline 1 & $\begin{array}{c}\text { Caulerpa taxifolia } \\
\text { 18SrRNA gene }\end{array}$ & 638 & 638 & $59 \%$ & $2 \mathrm{e}-178$ & $88.87 \%$ & AJ299788.1 \\
2 & $\begin{array}{c}\text { C. taxifolia } \\
\text { 18SrRNA gene } \\
\text { C. taxifolia }\end{array}$ & 636 & 636 & $59 \%$ & $6 \mathrm{e}-178$ & $88.73 \%$ & AJ299789.1 \\
3 & 632 & 632 & $59 \%$ & $8 \mathrm{e}-177$ & $88.73 \%$ & AJ299784.1 \\
4 & $\begin{array}{c}\text { 18SrRNA gene } \\
\text { C. taxifolia }\end{array}$ & 630 & 630 & $59 \%$ & $3 \mathrm{e}-176$ & $88.73 \%$ & AJ299775.1 \\
5 & $\begin{array}{c}\text { 18SrRNA gene } \\
\text { C. taxifolia }\end{array}$ & 627 & 627 & $59 \%$ & $4 \mathrm{e}-175$ & $88.55 \%$ & AJ299790.1 \\
6 & $\begin{array}{c}\text { 18SrRNA gene } \\
\text { C. taxifolia }\end{array}$ & 627 & 627 & $59 \%$ & $4 \mathrm{e}-175$ & $88.59 \%$ & AJ299776.1 \\
7 & $\begin{array}{c}\text { 18SrRNA gene } \\
\text { C. taxifolia }\end{array}$ & 627 & 627 & $59 \%$ & $4 \mathrm{e}-175$ & $88.59 \%$ & AJ299772.1 \\
8 & $\begin{array}{c}\text { C. taxifolia } \\
\text { CTCB3-6 }\end{array}$ & 625 & 625 & $59 \%$ & $1 \mathrm{e}-174$ & $88.33 \%$ & AY034869.1 \\
9 & $\begin{array}{c}\text { C. taxifolia isolate } \\
\text { St-Cyprien France }\end{array}$ & 625 & 625 & $59 \%$ & $1 \mathrm{e}-174$ & $88.41 \%$ & AJ228960.1 \\
10 & $\begin{array}{c}\text { C. taxifolia } \\
\text { 18SrRNA gene }\end{array}$ & 623 & 623 & $59 \%$ & $5 \mathrm{e}-174$ & $88.50 \%$ & AJ299786.1 \\
\hline
\end{tabular}


Table 3. Result of BLAST analysis of sample 2.

\begin{tabular}{|c|c|c|c|c|c|c|c|}
\hline No. & Description & $\begin{array}{l}\text { Max } \\
\text { Score }\end{array}$ & $\begin{array}{l}\text { Total } \\
\text { Score } \\
\end{array}$ & $\begin{array}{l}\text { Query } \\
\text { Cover }\end{array}$ & $\begin{array}{c}\text { E - } \\
\text { Value }\end{array}$ & $\begin{array}{c}\text { Per. } \\
\text { Identity }\end{array}$ & Accession \\
\hline 1 & $\begin{array}{c}\text { C. taxifolia } \\
\text { 18SrRNA gene }\end{array}$ & 1033 & 1033 & $65 \%$ & 0.0 & $95.20 \%$ & AJ299767.1 \\
\hline 2 & СТCB3-6 & 1027 & 1027 & $66 \%$ & 0.0 & $95.07 \%$ & AY034869.1 \\
\hline 3 & 18SrRNA gene & 1027 & 1027 & $65 \%$ & 0.0 & $95.05 \%$ & AJ299753.1 \\
\hline 4 & 18SrRNA gene & 1022 & 1022 & $65 \%$ & 0.0 & $94.89 \%$ & AJ299773.1 \\
\hline 5 & $\begin{array}{c}\text { isolate Le Brusc } \\
\text { France clone A }\end{array}$ & 1020 & 1020 & $66 \%$ & 0.0 & $94.77 \%$ & AJ228969.1 \\
\hline 6 & 18SrRNA gene & 1018 & 1018 & $66 \%$ & 0.0 & $94.76 \%$ & AJ299769.1 \\
\hline 7 & 18SrRNA gene & 1018 & 1018 & $66 \%$ & 0.0 & $94.76 \%$ & AJ299743.1 \\
\hline 8 & $\begin{array}{l}\text { C. taxifolia } \\
\text { 18SrRNA gene }\end{array}$ & 1016 & 1016 & $66 \%$ & 0.0 & $94.76 \%$ & AJ299776.1 \\
\hline 9 & $\begin{array}{l}\text { C. taxifolia } \\
\text { 18SrRNA gene }\end{array}$ & 1016 & 1016 & $65 \%$ & 0.0 & $94.74 \%$ & AJ299 775.1 \\
\hline 10 & $\begin{array}{l}\text { C. taxifolia } \\
\text { 18SrRNA gene }\end{array}$ & 1014 & 1014 & $66 \%$ & 0.0 & $94.76 \%$ & AJ299772.1 \\
\hline
\end{tabular}

\section{Phylogenetic Tree Analysis}

Phylogenetic tree analysis results from the 18SrRNA gene were obtained from Neighbor-Joining and compared with 8 other sequences for Sample 1 and 13 sequences for Sample 2. The sequences used were the Caulerpa species sequences from NCBI. The results showed that the sample 1 species had a close kinship with $C$. Sertularioides $f$. longipes, whereas for sample 2 it had a close kinship with $C$. taxifolia. The results of the phylogenetic tree for both samples are presented in Figures 4 and 5 below.

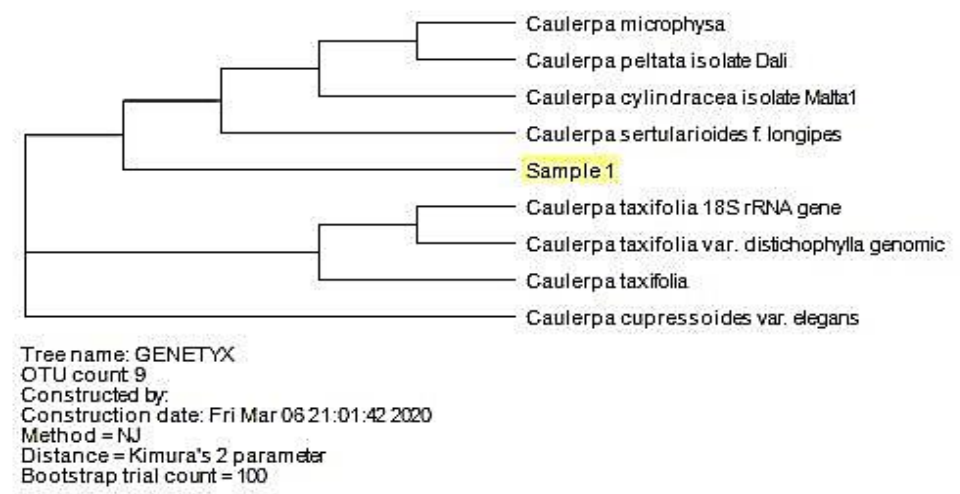

Figure 4. Phylogenetic tree of sample 1 showing a close kinship with $C$. Sertularioides $f$. longipes.
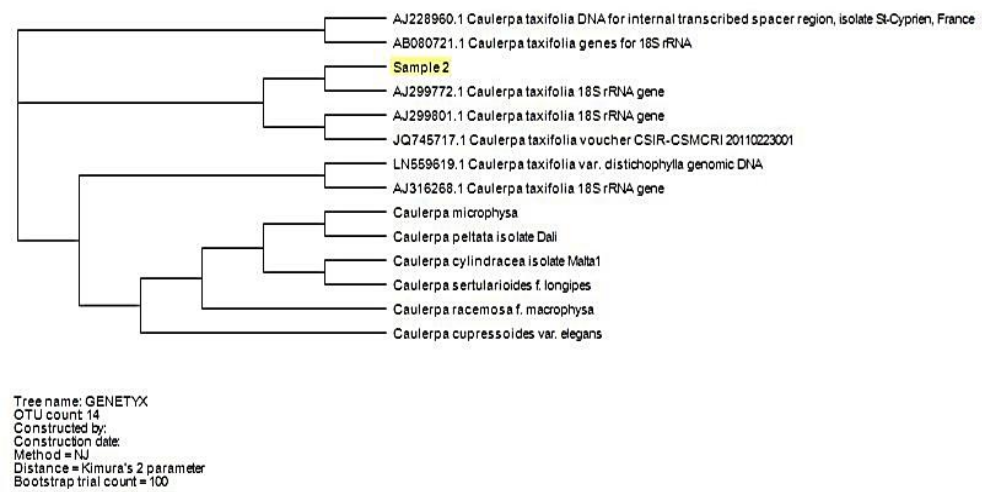

Figure 5. Phylogenetic tree of sample 2 showing close kinship with C. taxifolia. 
The results of phylogenetic analysis with maximum consensus like-hood of sample 1 actually had similarities with Caulerpa sertularioides $f$. longipes. These results support the findings of previous studies such as Mahendran and Saravanan (2017) whose algae sample had a 96\% similarity with Caulerpa taxifolia 18SrRNA gene, ascertaining that primer 18SrRNA can be used for molecular identification. However, the BLAST results were not supported by phylogenetic trees in sample 1 because synonymously $C$. taxifolia has similarities with C. Mexicana (Sonderex Kutzing, 1849) and C. taxifolia var. falcifolia. The similarity in our current study with previous studies (Wang et al., 2019; Mahendran and Saravanan, 2017) whom all found their studied Caulerpa species closely related to other Caulerpa species on their respective phylogenetic tree is one affirmation that our current study and those of the authors have been performed on related species of the same genus. The difference in the result of our sample 1 may be due to the small number of Caulerpa sequences used in phylogenetic tree analysis when compared to sample 2 .

\section{Various DNA Markers Used for Molecular Identification of Seaweed from Different Regions}

Some research results from the use of DNA markers as a method of molecular identification of seaweed reported in different parts of the world are presented in Table 4 below.

Table 4. DNA markers were used for seaweed identification.

\begin{tabular}{|c|c|c|c|}
\hline Species & DNA Marker & Region & Reference \\
\hline Spirogyra ellipsospora & ISSR and rbcL & Thailand & $\begin{array}{l}\text { Wongsawad and } \\
\text { Peerapornpisal (2014) }\end{array}$ \\
\hline Spirogyra maxima & $\mathrm{rbcL}$ & California & Stancheva et al. (2013) \\
\hline $\begin{array}{l}\text { - Dictyota sp. } \\
\text { - Halimeda sp. } \\
\text { - Padina sp. } \\
\text { - Polysiphonia sp. } \\
\text { - Sargassum sp. }\end{array}$ & ITS2 & $\begin{array}{l}\text {-Tomini Bay, Indonesia } \\
\text {-Tomini Bay } \\
\text {-Tomini Bay } \\
\text {-Tomini Bay } \\
\text {-Banten, Indonesia }\end{array}$ & Dharmayanti et al. (2018) \\
\hline $\begin{array}{l}\text { Kappachycus Doty } \\
\text { and Eucheuma J. } \\
\text { Agardh }\end{array}$ & $\begin{array}{l}\operatorname{Cox} 1, \operatorname{Cox} 2-3 \\
\text { spacer, Cox } 2 \\
\text { and rbcL }\end{array}$ & Southeast Asia & Tan et al. (2012) \\
\hline Ulva lactuca and & rbcL and & Gulf of Mannar, South & Mahendran and Saravanan \\
\hline Caulerpa taxifolia & 18SrRNA & East coast India & (2017) \\
\hline Caulerpa taxifolia & 18SrRNA & Mediterranean Sea & Jousson et al. (1998) \\
\hline Sargassum sp. & $\mathrm{COI}$ & $\begin{array}{l}\text { Krakal Beach, Yogyakarta, } \\
\text { Indonesia }\end{array}$ & Setyawan (2019) \\
\hline Brown Seaweed & $\begin{array}{l}\text { rbcL and partial } \\
\text { Cox } 1\end{array}$ & $\begin{array}{l}\text { Malaysia and Lombok, } \\
\text { Indonesia }\end{array}$ & Poong et al. (2014) \\
\hline $\begin{array}{l}\text { Caulerpa } \\
\text { taxifolia18SrRNA }\end{array}$ & 18SrRNA & $\begin{array}{l}\text { Mandangin Coastal, } \\
\text { Indonesia }\end{array}$ & Current study \\
\hline
\end{tabular}

The use of DNA markers for molecular identification of seaweed in several regions was highlighted in Table 4. Moreover, studies have shown that molecular identification of Spirogyra can be determined through molecular biology approach using rbcL primer (Stancheva et al., 2013; Wongsawad and Peerapornpisal, 2014). The results of research from Dharmayanti et al. (2018) submitted that the Internal Transcribed Spacers 2 (ITS2) DNA marker can be used for molecular identification of several types of algae collected from the Tomini Bay and Banten Bay in Indonesia.

This study has shown that molecular identification of Caulerpa species can use DNA barcoding as an 18SrRNA primer. In 
addition to the use of this primer, several genetic markers such as ITS-2, Rubisco, MSTSP, Cox3 and rbcL can be used for molecular identification of algae. PCR results with 18SrRNA primers in this study showed a band at a length of about 1000 bp. The same results were reported by Yeh and Chen (2004) that rDNA sequences were around 872-1124 bp length when amplified using PCR in 11 Caulerpa individuals and compared with several other Caulerpa species. Some researchers also mentioned that the success of molecular identification with barcode markers can vary depending on the size, geographical range and availability of the species dataset identified (Mattio and Payri, 2010). The results of this study are the first step in molecular identification of Caulerpa green algae in Indonesia and further research is needed on the identification of green algae with the use of other markers to support its knowledge of molecular taxonomy.

\section{CONCLUSION}

Based on the research performed, $18 S$ rRNA primers have been used for molecular identification of green seaweed from Mandangin for the first time and this shows that barcode markers can be used for molecular identification of seaweed, specifically Caulerpa in the waters of Mandangin Island, Indonesia. We suggest that further research be performed using other markers and different DNA extraction methods, order to facilitate the identification of other parts of the seaweed to obtain supporting results and develop Caulerpa green algae as medicinal ingredients and food for coastal people of Mandangin to improve their regional economy.

\section{ACKNOWLEDGEMENT}

We thank all parties who have aided in the completion of this research.

\section{REFERENCES}

Balata, D., Piazzi, L. and Cinelli, F., 2004. A comparison among assemblages in areas invaded by Caulerpa taxifolia and C. racemosa on a subtidal Mediterranean rocky bottom. Marine Ecology, 25(1), pp.1-13. https://doi.org/10.1111/j.1439-04 85.2004.00013.x.

Belton, G.S., van Reine, W.F.P.H., Huisman, J.M., Draisma, S.G. and D. Gurgel, C.F., 2014. Resolving phenotypic plasticity and species designation in the morphologically challenging Caulerpa racemosapeltata complex (Chlorophyta, Caulerpaceae). Journal of Phycology, 50(1), pp.32-54. https://doi.org/10 $.1111 /$ jpy.12132.

Bulleri, F., Balata, D., Bertocci, I., Tamburello, L. and BenedettiCecchi, L., 2010. The seaweed Caulerpa racemosa on Mediterranean rocky reefs: from passenger to driver of ecological change. Ecology, 91(8), pp.22052212. https://doi.org/10.1890/091857.1.

Camacho, O., Mattio, L., Draisma, S., Fredericq, S. and Diaz-Pulido, G., 2015. Morphological and molecular assessment of Sargassum (Fucales, Phaeophyceae) from Caribbean Colombia, including the proposal of Sargassum giganteum sp. nov., Sargassum schnetteri comb. nov. and Sargassum section Cladophyllum sect. nov. Systematics and Biodiversity, 13(2), pp.105-130. https://doi.org/10.1080/14772000 .2014.972478.

Chisholm, J.R., Fernex, F.E., Mathieu, D. and Jaubert, J.M., 1997. Wastewater discharge, seagrass decline and algal proliferation on the Cote d'Azur. Marine Pollution Bulletin, 34(2), pp.78-84. https:// doi.org/10.1016/S0025-326X(96)0 0072-0.

Cho, M., Lee, H.S., Kang, I.J., Won, M.H. and You, S., 2011. Antioxidant properties of extract and fractions from Enteromorpha prolifera, a type of green seaweed. Food Chemistry, 127(3), pp.999-1006. https://doi. 
org/10.1016/j.foodchem.2011.01.0 72.

Chomczynski, P., 1993. A reagent for the single-step simultaneous isolation of RNA, DNA and proteins from cell and tissue samples. Biotechniques, 15(3), pp.532-4. https://europepmc .org/article/med/7692896

Dawson, E.Y., 1954. Marine plants in the vicinity of the Institut Océanographique de Nha Trang, Viêt Nam. Pacific Science, 8, pp.373469. https://www.semanticscholar. org/paper/Marine-Plants-in-theVicinity-of-the-Institut-de-Dawson/ b8f4d6a47163baaed213d37efb42e 1eea47ba7ce.

Dharmayanti, N., Abinawanto and Anti, A., 2018, May. Using internal transcribed spacers 2 (ITS2) to identify seaweed species from Tomini Bay and Banten Bay. In IOP Conference Series: Earth and Environmental Science (Vol. 278, No. 1, p.012017). IOP Publishing. https: //doi.org/10.1088/1755-1315/278 /1/012017.

Doyle, J.J. and Doyle, J.L., 1990. Isolation ofplant DNA from fresh tissue. Focus, 12(13), pp.39-40. https:// www.researchgate.net/profile/Adhi tyo_Wicaksono/post/Quick_Extracti on_of_plant_DNA_does_anyone_ha ve_protocol/attachment/59d642 dc c49f478072eaba57/AS:273804717 166592@1442291539148/downloa d/Doyle\&Doyle_Focus_1990_CTAB. pdf

Farasat, M., Khavari-Nejad, R.A., Nabavi, S.M.B. and Namjooyan, F., 2013. Antioxidant properties of two edible green seaweeds from northern coasts of the Persian Gulf. Jundishapur journal of natural pharmaceutical products, 8(1), p.47 -52. https://doi.org/10.17795/jjnp p-7736.

Gennaro, P. and Piazzi, L., 2011. Synergism between two anthropic impacts: Caulerpa racemosa var. cylindracea invasion and seawater nutrient enrichment. Marine Ecology
Progress Series, 427, pp.59-70. http:/ /dx.doi.org/10.3354/meps09053.

Guiry, M.D., Guiry, G.M., Morrison, L., Rindi, F., Miranda, S.V., Mathieson, A.C., Parker, B.C., Langangen, A., John, D.M., Bárbara, I. and Carter, C.F., 2014. AlgaeBase: an on-line resource for algae. Cryptogamie, Algologie, 35(2), pp.105-115. https: //doi.org/10.7872/crya.v35.iss2.20 14.105.

Hoarau, G., Coyer, J.A., Stam, W.T. and Olsen, J.L., 2007. A fast and inexpensive DNA extraction/ purification protocol for brown macroalgae. Molecular Ecology Notes, 7(2), pp.191-193. https:// doi.org/10.1111/j.1471-8286.2006. 01587.x.

Jousson, O., Pawlowski, J., Zaninetti, L., Meinesz, A. and Boudouresque, C.F., 1998. Molecular evidence for the aquarium origin of the green alga Caulerpa taxifolia introduced to the Mediterranean Sea. Marine Ecology Progress Series, 172, pp.275-280. https://doi.org/10.3354/meps1722 75.

Kanegawa, K., Harada, H., Myouga, H., Katakura, Y., Shirahata, S. and Kamei, Y., 2000. Telomerase inhibiting activity in vitro from natural resources, marine algae extracts. Cytotechnology, 33(1-3), pp.221-227. https://dx.doi.org/10. 1023\%2FA\%3A1008179302906.

Kher, C.P., Doerder, F.P., Cooper, J., Ikonomi, P., Achilles-Day, U., Küpper, F.C. and Lynn, D.H., 2011. Barcoding Tetrahymena: discriminating species and identifying unknowns using the cytochrome c oxidase subunit I (cox1) barcode. Protist, 162(1), pp.2-13. https://doi.org/10.1016/j.protis.20 10.03.004.

Lane, C.E., Lindstrom, S.C. and Saunders, G.W., 2007. A molecular assessment of northeast Pacific Alaria species (Laminariales, Phaeophyceae) with reference to the utility of DNA barcoding. Molecular phylogenetics 
and evolution, 44(2), pp.634-648. https://doi.org/10.1016/j.ympev.2 007.03.016.

Lantah, P.L., Montolalu, L.A.D.Y. and Reo, A.R., 2017. Kandungan fitokimia dan aktivitas antioksidan ekstrak metanol rumput laut Kappaphycus alvarezii. Media Teknologi Hasil Perikanan, 5(3), pp.73-79. https:// doi.org/10.35800/mthp.5.3.2017.1 6785 .

Le Gall, L. and Saunders, G.W., 2010. Dna barcoding is a powerful tool to uncover algal diversity: A case study of the Phyllophoraceae (Gigartinales, Rhodophyta) in the Canadian flora 1. Journal of phycology, 46(2), pp.374-389. https: //doi.org/10.1111/j.1529-8817.20 10.00807.x.

Liu, Y., Morgan, J.B., Coothankandaswamy, V., Liu, R., Jekabsons, M.B., Mahdi, F., Nagle, D.G. and Zhou, Y.D., 2009. The Caulerpa pigment caulerpin inhibits HIF-1 activation and mitochondrial respiration. Journal of natural products, 72(12), pp.2104-2109. https://doi.org/10.1021/np900579 4.

Mahendran, S. and Saravanan, S., 2017. Molecular taxonomy of green seaweeds Ulva lactuca and Caulerpa taxifolia through phylogenetic analysis. Indian Journal of Geo Marine Sciences. 46(2), pp.414-419. http://nopr.niscair.res.in/handle/1 23456789/40765

Matanjun, P., Mohamed, S., Mustapha, N.M., Muhammad, K. and Ming, C.H., 2008. Antioxidant activities and phenolics content of eight species of seaweeds from north Borneo. Journal of Applied Phycology, 20(4), p.367-373. https:/ /doi.org/10.1007/s10811-007-926 4-6.

Mattio, L. and Payri, C., 2010. Assessment of five markers as potential barcodes for identifying Sargassum subgenus Sargassum species (Phaeophyceae, Fucales). Cryptogamie Algologie,
31(4), p.467-485. http://science press.mnhn.fr/sites/default/files/ar ticles/pdf/cryptogamie-algologie20 10v31f4a21.pdf

McKinnon, J.G., Gribben, P.E., Davis, A.R., Jolley, D.F. and Wright, J.T., 2009. Differences in soft-sediment macrobenthic assemblages invaded by Caulerpa taxifolia compared to uninvaded habitats. Marine ecology progress series, 380, pp.59-71. http:/ /dx.doi.org/10.3354/meps07926.

Meinesz, A., De Vaugelas, J., Hesse, B. and Mari, X., 1993. Spread of the introduced tropical green alga Caulerpa taxifolia in northern Mediterranean waters. Journal of applied Phycology, 5(2), pp.141-147. https://doi.org/10.1007/BF000040 09.

Oakes, J.M., Bautista, M.D., Maher, D., Jones, W.B. and Eyre, B.D., 2011. Carbon self-utilization may assist Caulerpa taxifolia invasion. Limnology and oceanography, 56(5), pp.1824-1831. https://doi.org/10.4 319/lo.2011.56.5.1824.

Pacciardi, L., De Biasi, A.M. and Piazzi, L., 2011. Effects of Caulerpa racemosa invasion on soft-bottom assemblages in the Western Mediterranean Sea. Biological invasions, 13(12), pp.2677-2690. https://doi.org/10.1007/s10530-01 1-9938-5.

Piazzi, L., Ceccherelli, G. and Cinelli, F., 2001. Threat to macroalgal diversity: effects of the introduced green alga Caulerpa racemosa in the Mediterranean. Marine ecology progress series, 210, pp.149-159. https://doi.org/10.3354/meps2101 49.

Poong, S.W., Lim, P.E., Phang, S.M., Sunarpi, H., West, J.A. and Kawai, H., 2014. A molecular-assisted floristic survey of crustose brown algae (Phaeophyceae) from Malaysia and Lombok Island, Indonesia based on rbcL and partial cox1 genes. Journal of applied phycology, 26(2), pp.1231-1242. 
https://doi.org/10.1007/s10811-01 3-0081-9.

Santiago-Vázquez, L.Z., Ranzer, L.K. and Kerr, R.G., 2006. Comparison of two total RNA extraction protocols using the marine gorgonian coral Pseudopterogorgia elisabethae and its symbiont Symbiodinium sp. Electronic Journal of Biotechnology, 9(5), pp. 599-603. https://doi.org/ 10.2225/vol9-issue5-fulltext-15.

Saunders, G.W. and Moore, T.E., 2013. Refinements for the amplification and sequencing of red algal DNA barcode and RedToL phylogenetic markers: a summary of current primers, profiles and strategies. Algae, 28(1), pp.31-43. https://doi. org/10.4490/algae.2013.28.1.031.

Setyawan, A., 2019. Fucoidan dari Alga Cokelat Tropis Sebagai Imunostimulan Udang Vannamei (Litopenaeus vannamei): Kajian Hematologi, Ekspresi Gen-gen Imun, Resistensi Terhadap WSSV dan Pertumbuhan. Disertasi. Universitas Gadjah Mada.Yogyakarta.

Shanmugam, H., Sathasivam, R., Rathinam, R., Arunkumar, K. and Carvalho, I.S., 2018. Algal Biotechnology: An Update From Industrial and Medical Point of View. In Omics Technologies and BioEngineering, pp. 31-52. Academic Press. https://doi.org/10.1016/b97 8-0-12-815870-8.00003-6.

Soylu, E.N. and Gönülol, A., 2012. Morphological and 18S rRNA analysis of coccoid green algae isolated from lakes of Kizılırmak Delta. Turkish Journal of Biology, 36(3), pp.247-254. https://doi.org/ 10.3906/biy-1001-19.

Stancheva, R., Hall, J.D., McCourt, R.M. and Sheath, R.G., 2013. Identity and phylogenetic placement of Spirogyra species (Zygnematophyceae, Charophyta) from California streams and elsewhere. Journal of phycology, 49(3), pp.588-607. https ://doi.org/10.1111/jpy.12070.
Tan, J., Lim, P.E., Phang, S.M., Hong, D.D., Sunarpi, H. and Hurtado, A.Q., 2012. Assessment of four molecular markers as potential DNA barcodes for red algae Kappaphycus Doty and Eucheuma J. Agardh (Solieriaceae, Rhodophyta). PLoS one, 7(12), pp.115. https://doi.org/10.1371/ journal.pone.0052905.

Varela-Álvarez, E., Andreakis, N., LagoLestón, A., Pearson, G.A., Serrao, E.A., Procaccini, G., Duarte, C.M. and Marba, N., 2006. Genomic DNA isolation from green and brown algae (caulerpales and fucales) for microsatellite library construction. Journal of phycology, 42(3), pp.741745. https://doi.org/10.1111/j.152 9-8817.2006.00218.x.

Vázquez-Luis, M., Sanchez-Jerez, P. and Bayle-Sempere, J.T., 2010. Effects of Caulerpa racemosa var. cylindracea on prey availability: an experimental approach to predation of amphipods by Thalassoma pavo (Labridae). Hydrobiologia, 654(1), pp.147-154. https://doi.org/10.1007/s10750-01 0-0378-5.

Verlaque, M. and Fritayre, P., 1994. Mediterranean algal communities are changing in the face of the invasive Alga Caulerpa-Taxifolia (Vahl) C Agardh. Oceanologica acta, 17(6), pp.659-672.

Vinayak, R.C., Sudha, S.A. and Chatterji, A., 2011. Bio-screening of a few green seaweeds from India for their cytotoxic and antioxidant potential. Journal of the Science of Food and Agriculture, 91(13), pp.2471-2476. https://doi.org/10.1002/jsfa.4490.

Wang, R., Liu, H., Wang, Y., Ke, H., Fan, J., Chen, F. and Tan, W., 2019. Complete chloroplast genome of green alga Caulerpa sertularioides $\mathrm{f}$. longipes (J. Agardh) Collins, 1909. Mitochondrial DNA Part B, 4(2), pp.3573-3574. https://doi.org/10.1 080/23802359.2019.1676668

Wongsawad, P. and Peerapornpisal, Y., 2014. Molecular identification and phylogenetic relationship of green 
algae, Spirogyra ellipsospora (Chlorophyta) using ISSR and rbcL markers. Saudi journal of biological sciences, 21(5), pp.505-510. https:// doi.org/10.1016/j.sjbs.2014.01.003

Yeh, W.J. and Chen, G.Y., 2004. Nuclear rDNA and internal transcribed spacer sequences clarify Caulerpa racemosa vars. from other Caulerpa species. Aquatic botany, 80(3), pp.193-207. https://doi.org/10.101 6/j.aquabot.2004.07.008.

Zubia, M., Robledo, D. and Freile-Pelegrin, Y., 2007. Antioxidant activities in tropical marine macroalgae from the Yucatan Peninsula, Mexico. Journal of applied phycology, 19(5), pp.449458. https://doi.org/ 10.1007/s108 11-006-9152-5. 